\title{
An Analysis on the Need for Cooperative Learning Model with RME Approach for Mathematics Learning of Elementary School
}

\author{
$1^{\text {st }}$ Shila Majid Ardiyani \\ Sebelas Maret University (UNS) \\ Surakarta, Indonesia \\ Corresponding author: \\ shilafanila@gmail.com
}

\author{
$2^{\text {nd }}$ Gunarhadi \\ Sebelas Maret University (UNS) \\ Surakarta, Indonesia \\ gunarhadi@fkip.uns.ac.id
}

\author{
$3^{\text {rd }}$ Riyadi \\ Sebelas Maret University (UNS) \\ Surakarta, Indonesia \\ riyadifkipuns@gmail.com
}

\begin{abstract}
Mathematics learning can stimulate the students to think critically and logically for the problem related to the real life. The initiation to mathematics learning for the first time at elementary. The aim of the research was to find out the need for cooperative learning model with Realistic Mathematics Education (RME) approach for mathematics learning in elementary school. This research was performed by descriptive qualitative approaches. The subject of research involved teacher and student respondents in the fifth grade of elementary schools in Karangpandan Sub District. An interview was performed to gain information from teachers and students. This techniques can reveal the implementation of mathematics learning in the classroom, also as a documentation to find out the mathematics learning outcome of students. This research suggested that cooperative learning model with RME approach can be used to improving the students' mathematics learning outcome. Due to some reasons: (1) most of the teacher still using conventional learning model; (2) students involvement in mathematics learning was still low, and (3) teachers didn't connect mathematics learning to students' real-life context.
\end{abstract}

Keywords-mathematics learning; cooperative learning; RME approach.

\section{INTRODUCTION}

Mathematics is called as a bridge of science; it is in line with Kumar \& Rao's opinion as follows that mathematics is the instrument for many other subjects [1]. One objective of mathematics education at school level is to encourage the students to think creatively and logically and be able to solve the problem related to daily life. Mathematics is one of the subjects taken by the students in formal education from Elementary School to College. Švecová stated that one objective of mathematics education is to prepare the students for dealing with the situation of real life effectively [2]. This can be inferred from the students mathematics learning outcome. In this case, the quality of Indonesian mathematics learning can be seen from National Exam (Ujian Nasional, after that called UN) result. The National Exam at elementary level consists of three subjects: Indonesian Language, Natural Science, and Mathematics. To represent the result of National Examination, Karangpandan Sub District was chosen as representative to analyze. Karangpandan is located in Karanganyar, Central Java, Indonesia. The result of National
Examination of 2016 in this area has lower than that of other two subjects. It was supported by the fact that the learning outcome for the 5th grade of Elementary Schools in Karangpandan showed that many students had not achieved yet the Minimum Passing Grade (KKM) for Mathemathics. Therefore, there should be an effort to improve and enhancing the quality of mathematics learning.

It is certain that the selection of learning model affected the learning process in the classroom. Learning mathematics using conventional method were dominated with lecturing. As the consequences of using conventional approach, students are difficult to works on the task independently at home. Longterm application of conventional method are not attempting to the student. In other words, it can be impact to student achievement in mathematics. To solve this problem, the learning model is required to make the learning more active, interactive, and joyful such as cooperative learning model. Eggen and Kauchak stated that cooperative learning is a group of teaching strategies that can increase the interaction between students [3]. This means that every student plays the more specific role than the usual group works. The cooperation between one and another for the sake of their life sustainability allows for the learning activities involving cooperation between students even in a small group. Aziz stated that cooperative learning model was developed by Johnson and Johnson (1994) to improve the students achievement and to help improve the relationship between students with different proficiency, improve self-esteem and develop a positive attitude to mathematics [4].

When it combined the learning model with an appropriate learning approach, can maximize the learning process. The convenient approaches to mathematics learning is Realistic Mathematics Education (RME). Realistic Mathematics Education (RME) was introduced and developed in the Netherlands in Freudenthal Institute in 1970. Freudenthal's argument states that mathematics should be connected to reality and mathematics itself was human activity. Dickinson \& Hough stated that Realistic Mathematics Education (RME) is a specific approach in mathematics education, based on a 
philosophy that the students should develop their mathematics understanding by working from daily reasonable context [5]. This mean relevant with the context of real-world such as with the students daily life. Thereby, the mathematics learning becomes more real. Mathematics learning with RME approach enables the students to think logically, creatively, and critically.

\section{METHODS}

This research is qualitative descriptive research. Understanding the needs of the importance of cooperative learning model with the RME approach to mathematics teaching elementary school. The population of the research covers the entire elementary school (SD) in Karangpandan Sub-district. The subject of this research is 5th grade students. Interview, observation, and documentation was performed to gain the data collection. Since it is a qualitative descriptive research, the interview was done to explore the information about the teachers and students role in mathematics learning. Direct observation was done to know the implementation of mathematics teaching in the classroom. The documentation of the results of learning mathematics students are gathered for further analysis.

\section{RESULT AND DISCUSSION}

The National Exam (UN) result can be seen in Table 1. Based on the result, elementary students in Karangpandan Sub District has lowest mean score in mathematics compared to other subjects. Considering the result of National Exam in 2016, the learning outcome of mathematics subject are classified good enough. However, the result is still not satisfying when it compares to other subject. This was confirmed by investigation to the learning outcome of the 5 th grade in five elementary schools. The result shows that the students who's successfully passing in mathematics learning is still below $50 \%$. This condition indicating the problem is facing in mathematics learning in elementary schools.

TABLE 1. National Exam Score in the school year of 2016/2017

\begin{tabular}{cccc}
\hline Subject & Indonesian Language & Natural Science & Mathematics \\
\hline Highest score & 8.67 & 9.7 & 9.5 \\
Lowest score & 6.4 & 7 & 5.82 \\
Mean score & 8.03 & 8.21 & 7.99 \\
\hline
\end{tabular}

(Source: UPT PUD NFI and Elementary Schools throughout Karangpandan Sub Districts)

\section{Instructional Model Applied by Teacher}

Based on observations during the process of learning mathematics in the classroom can be seen that teachers still use conventional models dominated by lectures, interaction occurs in one way from teachers to students, the students tend to behave passively, listening to silently. When students are given a matter of practice, there are still many who feel confused to do. Regarding the learning model applied by the teacher is explained in the citation of an interview with teachers as follows:
Author
: How is mathematics learning you do so far?
Teacher
: I usually explain the material along with some examples, and then I give the students exercises to find out their material mastery.
Author $\quad$ : What model or method do you usually apply to mathematics learning? Have you ever applied cooperative learning model?
Teacher : I still often use lecturing, dependent on the material. I have ever applied cooperative learning model in Science learning as its material is so much.

It is supported by the citation of an interview with students as follows:
Author
: What subject do you like?
Students
: Indonesian language, as I love read pantun (traditional poetry), poetry, and another story.
Author : Do you like mathematics?
Students $\quad$ : No I do not, because mathematics is very difficult and confusing.

From the explanation above, it can be known that teachers still applies conventional model dominated with lecturing by the teacher (teacher-centered) while students only listen to the teacher. Teachers are applies cooperative learning model in Science subject.

\section{The liveliness of Students in Class}

Observation show the activity of students during learning mathematics in the classroom were not involved interaction between students-students, also students-teacher. The interaction between students occurs when talking about anything out of the lesson topics. Students do exercises individually, there is no group discussion appears, students 
tend to have the mathematics learning passively and less excited. It is confirmed by an interview with teachers:

Author How is the students' activeness in attending
mathematics learning?
Teacher When I give an explanation, and I see that the
students are passive, I will ask them "Do you
understand?" the students answer "Yes I do,"
when I ask "Is there any question?" the
children keep silent. The students cannot be
active as expected. I have attempted to
stimulate the students to question actively, but
they keep silent so that I think that they have
understood, but when I give them exercise, only
one or two students can work on it.

It is supported by the citation of an interview with students as follows:
Author :Do you attend the mathematics learning
vigorously and actively?
Students

$$
\begin{aligned}
& \text { : I attend mathematics learning not vigorously } \\
& \text { compared with other subjects. }
\end{aligned}
$$

From the above exposure can be concluded that the students are still passive and less eager in following the math lesson.

\section{The Relationship Between Mathematics and Real-Life}

Based on observation finding that teachers did not use any media e. g. visual media or projector that can facilitates students in learning mathematics. Generally, teachers still rely on the textbook and worksheet in teaching. The relationship between mathematics and real-life can be seen in the citation of an interview with teachers below:

\section{Author : Have you related mathematics learning material to the students' daily life? \\ Teacher: Yes I sometimes have, because some can be related and some others cannot. Mathematics?Teacher : Most students have not known multiplication and division very well thereby inhibiting the next learning. \\ Author : So, what difficulty do you find during teaching}

From the explanation above, it can be concluded that teacher has connected mathematics material inadequately to the real-life context so that mathematics is still identical with memory (recitation).

Regarding the solution offered by the teacher, the result of an interview with teacher shows as follows:

Group discussion or cooperative learning is good. I have ever applied in the sixth grade, and the outcome is fairly good, the students can exchange information with their friends to solve the problem I have given. However, I have never applied it to the fifth grade.

The explanation above shows the need for an innovative learning model application to improve the students learning outcome and activeness. The conventional learning model, in this case, has some weaknesses: 1) communication occurring in one way (teacher-centered); 2) students tending to attend the learning passively; 3) the recitation material making the students forgetting easily; 4) limited media use, focusing only on textbook; and 5) students attending the learning less vigorously. When this conventional model is applied too long, it is well established that the students feel bored easily during the learning in the classroom and the mathematics' successfully passing score is still low. To solve this problem, a learning model is needed to make the learning active, interactive and joyful. One solution offered to solve this problem is to apply a cooperative learning model that can trigger the students activeness particularly in interacting with their friends to solve the problem. Through cooperative learning, the smart students can share knowledge with the other, also the other students can learn with the smart students so that a positive interaction occurs between students. Cooperative learning is consistent with social constructive principle held on by Vygotsky stating that the principle of constructivism for higher function lies beyond individual called interpersonal relation [6]. Thus, Vygotsky's theory emphasizes individual interaction with the social environment in the learning to obtain knowledge triggering cognitive development.

Cooperative learning model will provide a better result when it is combined with an appropriate approach. Hadi stated that Realistic Mathematics Education (RME) is considered in line with the learning theory developing so far, such as constructivism and contextual learning, but the advantage of RME is that it is developed specifically for mathematics [7]. RME was introduced and developed in the Netherlands by Freudenthal Institute in 1970. The application of RME is more flexible; the problem comes not only from real world as suggested by Panhuizen and Drijvers "... in RME, problems presented to students not only come from the real world but also from the fantasy world. This can be from a fairy tales, or the formal world of mathematics, as long as the problems are experientially real in the student's mind" [8]. So, the problem can come from anywhere as long as it can be imagined by the students mind.

The research related to cooperative learning by Othman, et al. suggests that the student's maturity is established as the result of experience with cooperative learning, particularly the establishment of positive social skill, such as the improvement of students behavior and interpersonal relation [9]. Through CL, the development of individual and group skills on work can improve the students achievement. It is in line with the improvement of students behavior and interpersonal relation. Nurhayati and Hartono suggest that the students using STAD 
type of cooperative learning model with RME approach have a better ability to understanding mathematics concept than those using regular learning [10]. Zubainur, Veloo, and Khalid have researched RME as well, concluding that there is a significant difference in mathematics learning outcome in elementary schools [11]. The findings showed that using the RME approach in mathematics instructions is effective. It shows that cooperative learning model and RME approach can give positive retribution to mathematics learning. However, this current research focuses on analyzing the need for learning model in mathematics at elementary school, particularly in the fifth grade.

\section{CONCLUSION}

Based on the data analysis, it can be concluded that the need for innovative learning model application is based on some reasons: (1) teacher still often applies conventional learning model; (2) students activeness in mathematics learning is still low; and (3) teacher rarely connects mathematics learning to the students real-life context. It impacts as well on the mathematics learning outcome of students who's passing had not achieved yet the Minimum Passing Criteria (KKM). The author concludes that there should be a follow-up related to the application of cooperative learning model with RME approach to trigger students activeness and to improve the mathematics learning outcome of students.

\section{ACKNOWLEDGMENTS}

I would like to thank my counselors in Sebelas Maret University Surakarta for their guidance in completing this article writing. I would express my gratitude as well to all of those involved in this research, particularly teachers and students in the fifth grade of elementary schools in Karangpandan Sub District.

\section{REFERENCES}

[1] S. J. V. Kumar and D. B. Rao, Techniques of Teaching Mathematics (Sonali Publications, New Delhi, 2006), pp. 1-2.

[2] V. Švecová, L. Rumanová, and G. Pavlovičová, "Support of Pupil's Creative Thinking in Mathematical Education," in Procedia Social and Behavioral Sciences, (Elsevier Ltd., 2014), pp. 1715-1719.

[3] P. Eggen and D. Kauchak, Strategi dan Model Pembelajaran: Mengajarkan Konten dan Keterampilan Berpikir (PT Indeks, Jakarta, 2012). p. 136.

[4] Z. Aziz and M. A. Hossain, "A comparison of cooperative learning and conventional teaching on student's achievement in secondary mathematics," in Procedia Social and Behavioral Sciences, (Elsevier Ltd., 2010), pp. 53-62.

[5] P. Dickinson and S. Hough, Using Realistic Mathematics Education in UK classrooms, (2012), p. 1.

[6] L. S. Vygotsky, Thought, and Language (Massachusetts Institute of Technology, USA, 1986), p. 26.
[7] S. Hadi, Pendidikan Matematika Realistik: Teori, Pengembangan, dan Implementasinya (PT Raja Grafindo Persada, Jakarta, 2017), p. 37.

[8] M. V. D. H. Panhuizen and P. Drijvers, "Realistic Mathematics Education," in Encyclopedia of Mathematics Education, edited by S. Lerman (Utrecht University, Utrecht, The Netherlands, 2014), pp. 521525 .

[9] H. Othman, I. Asshaari, H. Bahaludin, N. M. Tawil, and N. A. Ismail, "Students' Perceptions on Benefits Gained from Cooperative Learning Experiences in Engineering Mathematics Courses," in Procedia Social and Behavioral Sciences (Universiti Kebangsaan Malaysia, Malaysia, 2012), pp. 500-506.

[10] D. M. Nurhayati and Hartono, "Implementation of Cooperative Learning Model Type STAD with RME Approach to Understanding of Mathematical Concept Student State Junior High School in Pekanbaru," in Mathematics, Science, and Computer Science Education (MSCEIS 2016), AIP Conference Proceedings 1848, (Universitas Pendidikan Indonesia, Bandung, Indonesia, 2016), pp. 040002-1-040002-5.

[11] C. M. Zubainur, A. Veloo, and R. Khalid, "The Effect of Using Indonesian Realistic Mathematics Education (PMRI) Approach Amongst Primary School Students," in International Conference on Mathematics, Engineering and Industrial Applications 2014 (ICoMEIA 2014), AIP Conference Proceedings 1660, (Universitas Syah Kuala, Aceh, Indonesia, 2014), pp. 050077-1-050077-5. 